\title{
THE ASSOCIATION HYPERICO-EUPHORBIETUM GLABRIFLORAE REXHEPI 1978 IN THE SERPENTINE TERRAINS OF DRENICA MOUNTAIN
}

\author{
Elez KRASNIQI*\&** \& Fadil MILLAKU**
}

\begin{abstract}
In the territory of Kosovo there are many serpentine mountain massifs. The largest complexes are found in the valley of the Ibër River, and the same are continued in a discontinuous chain through Koznica and Golesh to the southwest of the territory of Kosovo. Vegetation on the serpentine bedrock is rich in rare species and communities, which cannot be found in the Balkans and Europe. The communities appearing on the serpentine bedrock are characteristic and important for science. They are endemic due to the presence of endemic species in their species composition. Drenica Mountain $(1051 \mathrm{~m})$ is part of the Central Kosovo Mountains. These terrains are situated in the central part of Kosovo, between Ciçavica, Kosovo plain (Golesh), Llapusha, the Carraleva Mountains and the Anadrini region. A considerable part of these areas consists of serpentine bedrock, which is covered by interesting flora and vegetation. In the vegetation of Drenica Mountain 10 communities have been identified. Two of them are found on serpentine bedrock: ass. Hyperico-Euphorbietum glabriflorae and ass. Potentillo-Fumanetum bonapartei. These communities belong to the open space, and are also located in other parts of Kosovo, but only on serpentine bedrock. On Drenica Mountain there are two localities where these two communities appear. In this paper we focus in particular on ass. Hyperico-Euphorbietum glabriflorae.
\end{abstract}

Key words: Drenica Mountain, Serpentine terrains, ass. Hyperico-Euphorbietum glabriflorae Rexhepi 1978, Kosovo, vegetation.

Izvleček

Na Kosovu so številni gorski masivi iz serpentinita. Največje površine so v dolini reke Ibër. Nadaljujejo se v prekinjeni verigi skozi Koznico in Golesh proti jugozahodnem delu Kosova. Vegetacija na serpentinitu je bogata z redkimi vrstami in združbami, ki ne uspevajo nikjer drugje na Balkanu in v Evropi. Te združbe na serpentinitu so pomembne, ker vsebujejo endemične vrste. Drenica $(1051 \mathrm{~m})$ je del osrednjega gorovja na Kosovu. To območje se nahaja v osrednjem delu Kosova, med kraji Çiçavica, Golesh, Llapusha, gorovjem Carraleva in območjem Anadrini. Precejšen del območja je na serpentinitu. V vegetaciji gore Drenica je najdenih deset združb. Dve sta na serpentinitu: asociacija Hyperico-Euphorbietum glabriflorae in asociacija Potentillo-Fumanetum bonapartei. Najdemo ju na odprtih rastiščih. Na Drenici sta dve najdiščiteh dveh združb. V članku je predstavljena predvsem asociacija Hyperico-Euphorbietum glabriflorae.

Ključne besede: Drenica, serpentinit, Hyperico-Euphorbietum glabriflorae Rexhepi 1978, Kosovo, vegetacija.

\section{INTRODUCTION}

Serpentine bedrock is spread all over the world, and scientists dedicate special attention to researching the geologic, chemical and petrographical conditions of the flora and fauna. Serpentine is rarely found on the surface of the earth (Kruckeberg 1985). In the Balkan Peninsula there appear serpentine rocks with interesting and rich flora and vegetation. Kosovo, which is situated in the central part of the Balkans has very interesting serpentine

\footnotetext{
* MESP (Ministry of Environment and Spatial Planning), KINP (Kosovo Institute for Nature Protection), Bill Clinton Boulevard., Lam A/1, 10 000, Prishtinë, Kosovë, elez_krasniqi@yahoo.com

** UP (University of Prishtina), The Faculty of Mathematics and Natural Sciences; Nëna Terezë str. n.n. 10000, Prishtinë, Kosovë, fadilmillaku@yahoo.com
} 


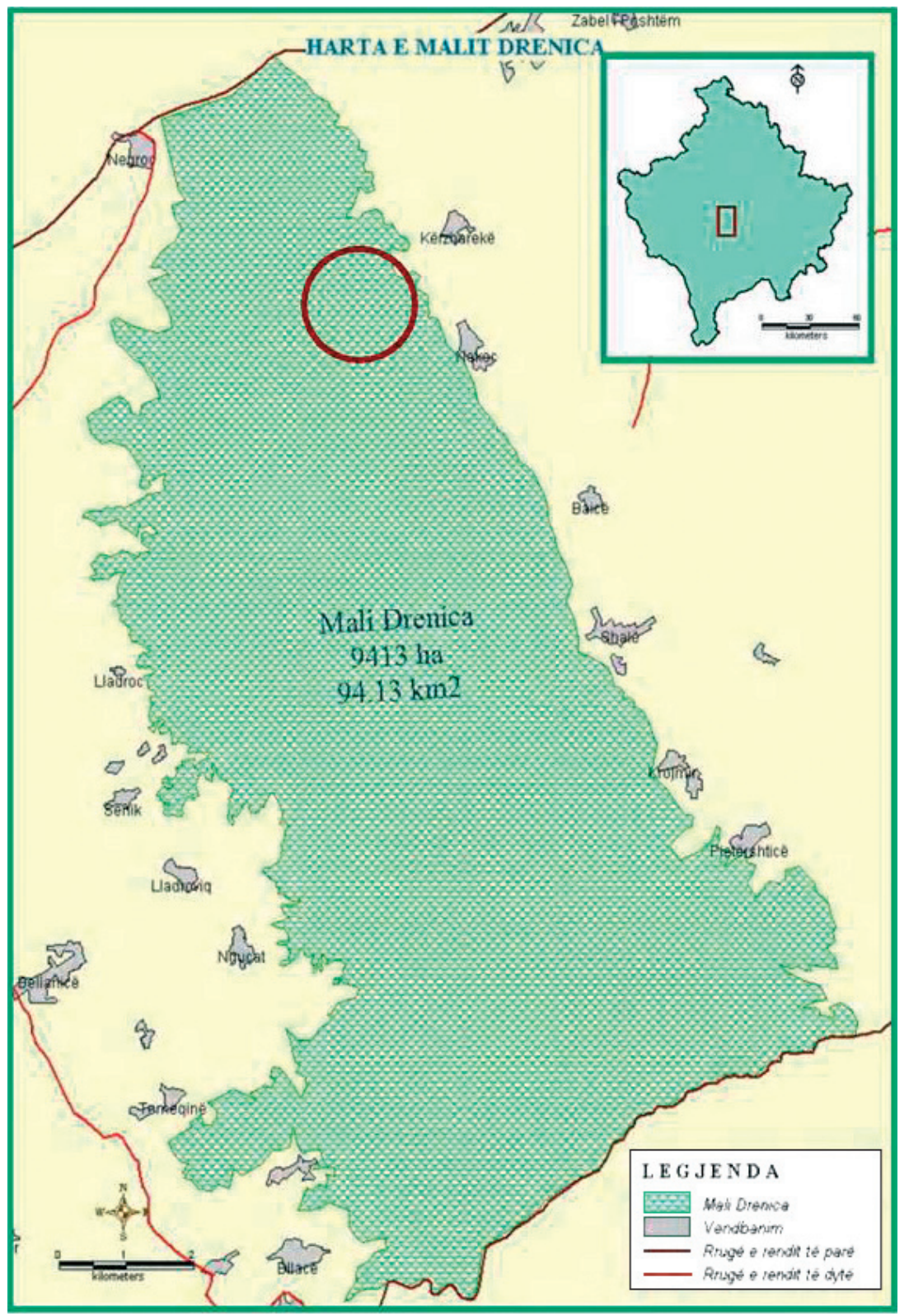

Figure 1: The map of Drenica Mountain (MESP - GIS. 2005) O The locality of the community.

Slika 1: Zemljevid Drenice (MESP - GIS 2005), z označeno lokaliteto združbe. territory (Rexhepi 1985), and considering the climate, altitude and anthropogenic factors, the resulting flora and vegetation are very diverse.

Throughout the territory of Kosovo there are many basic and ultra basic rocks, which are known by their common name as "serpentine". The largest complexes of serpentines are situated in the valley of the Ibër river, Golesh, the Sharr Mountains (Maja e Pashallarëve-Ostrovicë), the Albanian Alps (Gubavc), Koznik, the Mirusha region, Mushtisht, Gjakova surroundings, Koznicë, Guranë, Badovc and the Drenica Mountain.

The serpentine rocks in the Kosovo territory, belong to the cretaceous age. Their chemical composi- tion consists mainly of magnesium, silica and iron, while other elements are present in smaller quantities. Due to the small amount of biogenic elements necessary for plant life, serpentine terrains are not suitable for the development of plants. Such a chemical structure is the main reason for the unique flora and vegetation in these terrains (Rexhepi 1978).

Referring to the researches of the floristic composition in serpentine areas, we emphasise some plant categories such as: relict serpentinophytes, typical (exclusive) serpentinophytes and plants which predominantly thrive on serpentines, indifferent plants (very often to be found on serpentine) and serpentinemorphosis . On the serpentine area all types of 
vegetation are found: forest and bush (shrub) and herbaceous communities (Rexhepi 1985).

Flora and vegetation on serpentine bedock in Kosovo have been investigated by many researchers: Blečić et al. (1969), Blečić \& Krasniqi (1971), Krasniqi (1972), Rexhepi (1978, 1979, 1982, 1994, 2000), Krasniqi (2003, 2006), Krasniqi \& Millaku (2004) etc.

The aim of our study is to sample the dry grassland of the Hyperico-Euphorbietum glabiflorae, to analyse its floristic inventory and to show some peculiarities. At the same time we would like to present also the site conditions of the communties and to present and analyse serpentine vegetation on Drenica mountain.

\section{MATERIALS AND METHODS}

\subsection{Description of the researched area}

Drenica Mountain $(1051 \mathrm{~m})$ is part of the central mountains in Kosovo, respectively the western part of mountains of the Drenica region, in contact with: Kasmaç (976 m), Gradina e Vogël, Gradina Madhe $(940 \mathrm{~m})$, Buleni $(740 \mathrm{~m})$ and Mali i Lisit të gjatë $(856 \mathrm{~m})$. The area is situated in the central part of Kosovo, between Ciçavica, Kosovo plain, Golesh, Llapusha, the Carraleva Mountains and Anadrini.

The Llapushnik-Carralevë territory of Drenica Mountain includes areas with different substrates and natural habitats, where the major part is covered by forests while the other parts are grasslands and paddocks. A large part of this mountain is grassland over a serpentine substrate (Pavičević et al. 1974, Krasniqi 2006). In the serpentine terrains of Drenica Mountain, there appear two communities identified: Hyperico-Euphorbietum glabriflorae Rexhepi 1978 and Potentillo-Fumanetum bonapartei Rexhepi 1979 (Krasniqi 2006).

The center of the community Hyperico-Euphorbietum glabriflorae is situated in the coordinates: $\mathrm{X}=0490902$ and $\mathrm{Y}=4708414$ (measured with GPS). Altitude is $730-895 \mathrm{~m}$. Slope is $5-30$ with the dominant aspect Northeast and North.

Brownized rendzina over serpentine bedrock is the predominant soil type where the community Hyperico-Euphorbietum glabriflorae (Figure 2) thrives (Pavičevič 1974, Krasniqi 2006).

The Drenica Mountain area has a continental climate, from time-to-time hostile, under the influence of predominant wind direction from the Northeastern part of the region (Tahirsylaj 2004).

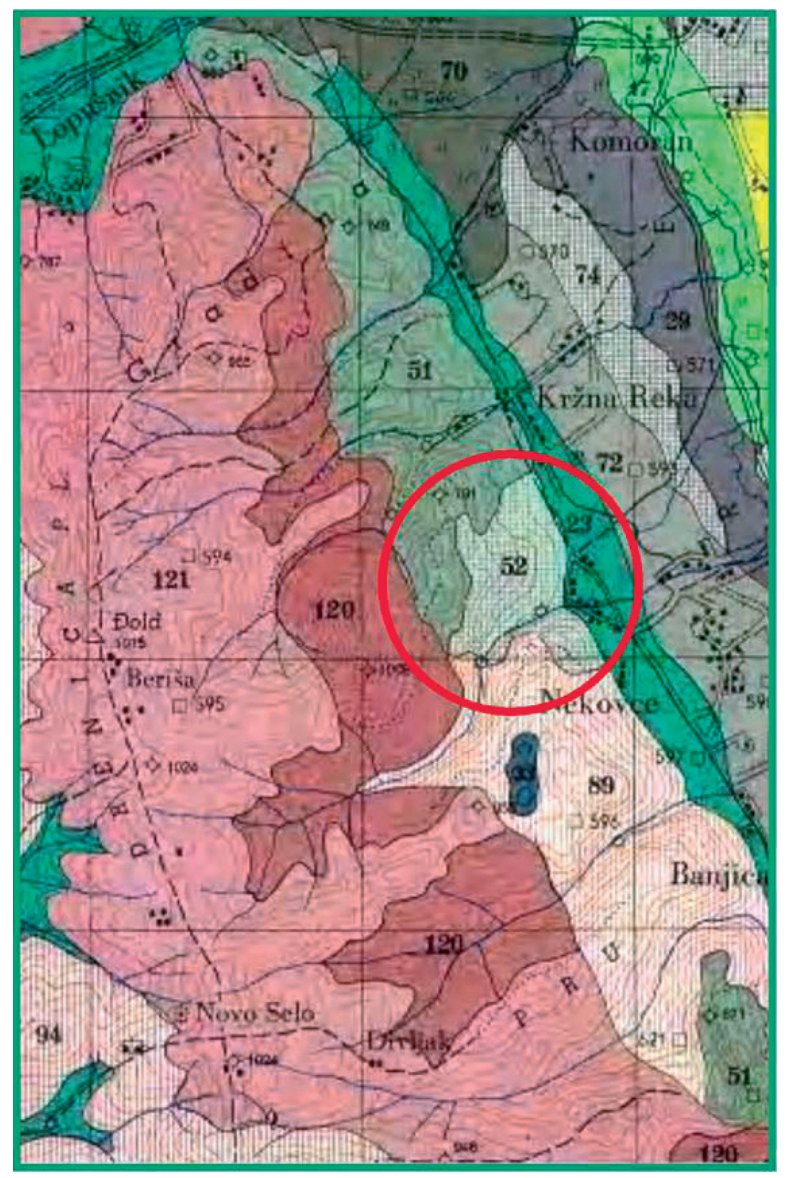

Figure 2: The pedological map of Drenica Mountain (52. Brownized rendzina on serpentine) (Pavičevič 1974, Krasniqi 2006).

Slika 2: Pedloška karta pogorja Drenica (52. rendzina na serpentinitu) (Pavičevič 1974, Krasniqi 2006).

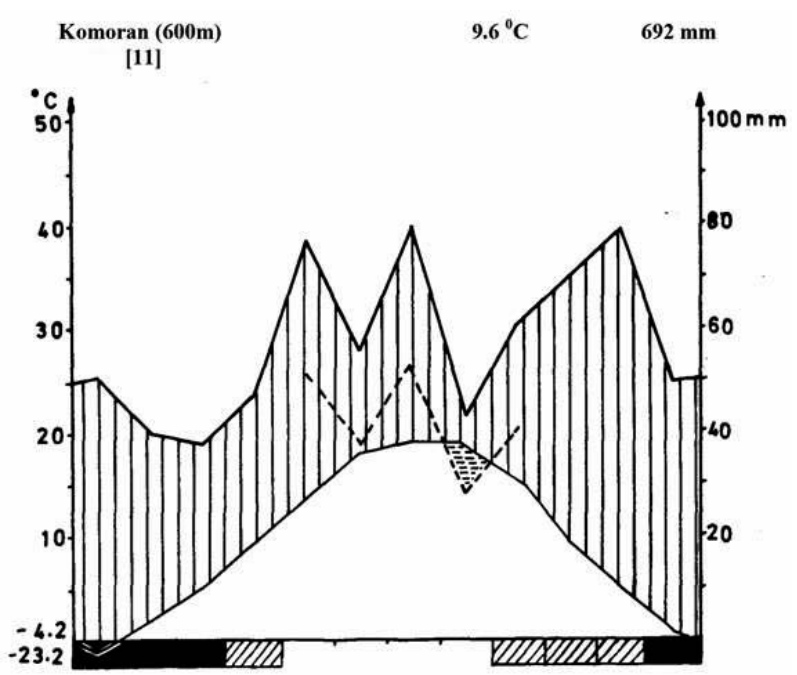

Figure 3: Climatic diagram of Komoran.

Slika 3: Klimatski diagram mesta Komoran. 
The relationship between the air temperature and rainfall is presented in the climate diagram of Komoran (a locality next to the researched location) (Figure 3).

\subsection{Methods}

Vegetation is studied according to the principles and methods of the Zürich-Montpellier School (Braun-Blanquet 1964). In the research work done in Kosovo, this method has also been used by Blečić et al. (1969), Krasniqi (1972), Rexhepi (1978, 1982, 1994, 2007), Hundozi (1980, 1987), Pajazitaj (2000) and Krasniqi (2006). The elementary activities in the field have been the identification and determination of homogeneous plots. This has been completed on the basis of field analyses of the floristic composition of each relevé in a certain community, together with other additional data, such as number of relevé, altitude, aspect, slope, bedrock and the size of each relevé $\left(\mathrm{m}^{2}\right)$. The floristic composition assigned to higher syntaxonomic categories (class, order and alliance) is presented according to the principles of characteristic species assignment to these categories (Rexhepi 1978, 1982, 1994, Mucina et al. 1993, Čarni et al. 2000). The arranging of all characteristic species of syntaxonomic categories is made according to the constancy class, beginning from grade $\mathrm{V}$ to I. This is the same as for the classification of accompanying plant species in the community (Rexhepi 1994, Buzo 2005).

\section{RESULTS}

\subsection{Syntaxonomical scheme}

\section{FESTUCO - BROMETEA Br. Bl. et R. Tx. 1943 HALACSYETALIA SENDTNERI Rt. 1970 \\ Centaureo - Bromion fibrosi Blečić et al. 1969 Hyperico - Euphorbietum glabriflorae Rex- hepi 1978}

\subsection{Floristic composition of the Community}

The floristic composition of the community is presented in the phytocoenological table (Table 1) with 10 relevés. In the table, there are 80 species present. Characteristic species of the association are: Euphorbia glabriflora, Potentilla australis, Linum tauricum var. serbicum, Hypericum barbatum, Potentilla visianii and Scorzonera austriaca. For all character species the locality of Drenica mountain is new for this species in the flora of Kosovo.

Euphorbia glabriflora Vis. (Figure 4). A small spineless shrub 10-20 cm, of stony mountain slopes, with lanceolate to linear-lanceolate leaves and obovate yellowish floral bracts. Rays usually 3-5, each with one "flower". Fruit globular, with long cylindrical swellings (Polunin 1997). Is spread throughout the Balkan Peninsula: Albania, Bosnia and Herzegovina, Montenegro, Macedonia and Greece (Tutin et al. 1968, Josifović 1972, Qosja et al. 1992, Polunin 1997). It belongs to the Balkan floristic element (Rexhepi 1994). In Kosovo, it is found in Golesh, Koznicë, Ibër river valley, Mirusha region, Zatriq, Golesh of Malisheva, Dritan (Dobroshefc), Shkabaj (Gllanasellë) and Drenica Mountain (Krasniqi 2006).

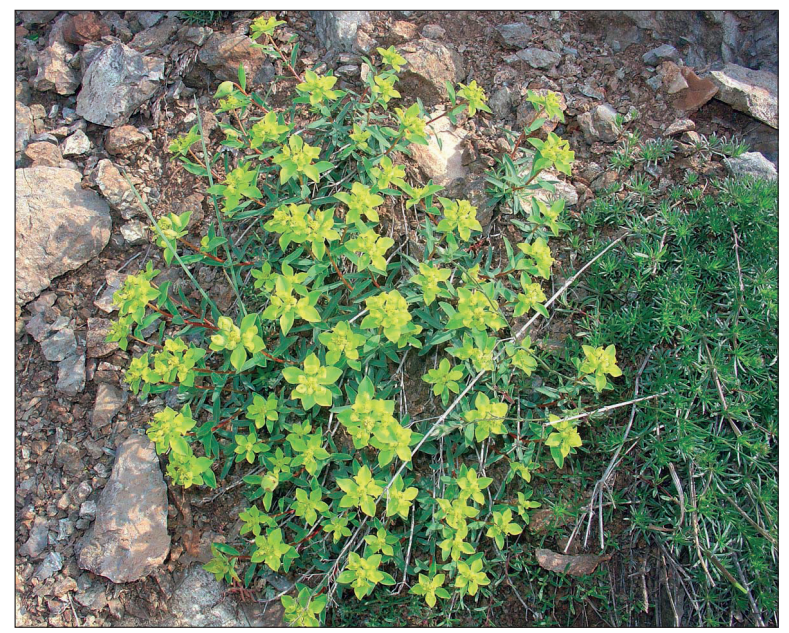

Figure 4 (Slika 4): Euphorbia glabriflora.

Hypericum barbatum Jacq. (Figure 5). Leaves $0.6-4 \mathrm{~cm}$, lanceolate to linear-lanceolate or ellipticoblong, stalkless or nearly so; stem $10-45 \mathrm{~cm}$. Yellow petals usually with black dots over the surface or towards apex only. Sepals with non-glandular hairs along the margin and with numerous superficial black dots and streaks. Orange glands on fruit not prominent. Meadows, stony places (Polunin 1997). Is spread in Southeastern Europe, mainly in the Balkan Peninsula (Albania, Kosovo, Serbia, Macedonia, Bulgaria and Greece), extending to Austria and S. Italy (Tutin et al. 1968, Josifović 1972, Qosjca et al. 1992, Polunin 1997). It belongs to the Balkan floristic element (Rexhepi 1994). In Kosovo, it is found in Golesh, Mirusha region (Koznik) and Drenica Mountain (Krasniqi 2006). 


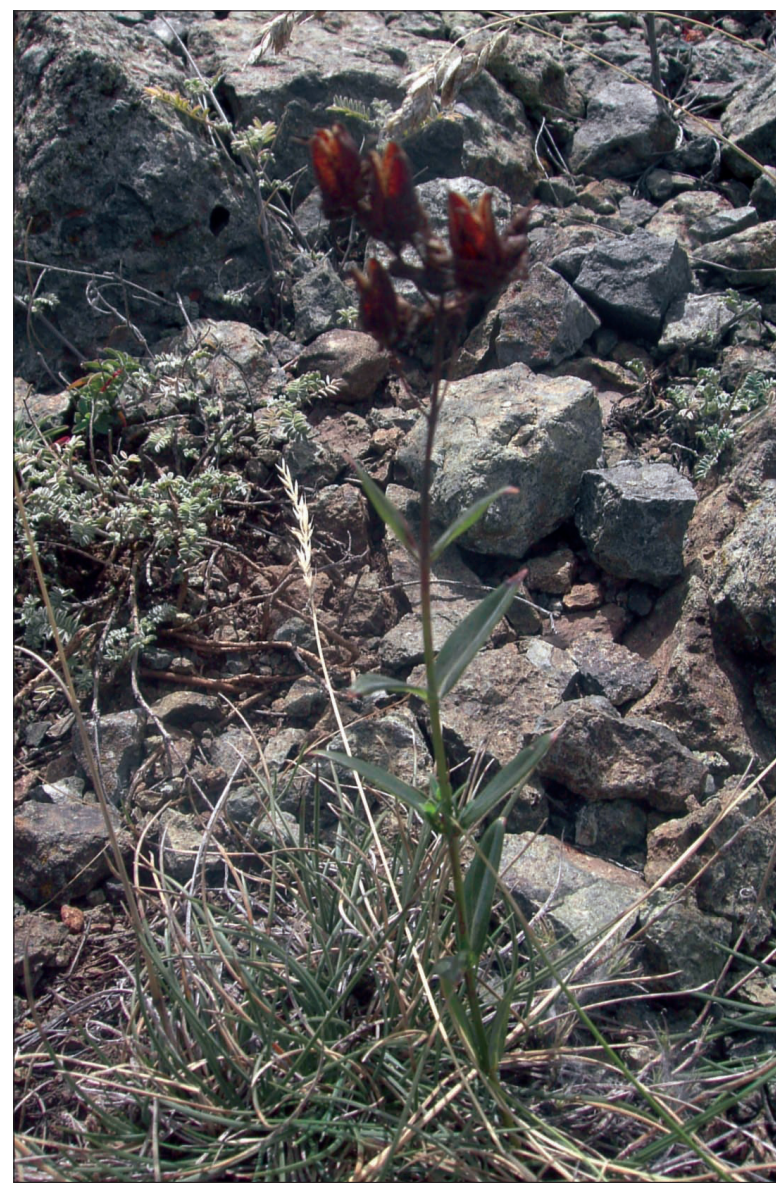

Figure 5 (Slika 5): Hypericum barbatum.

Potentilla australis Krasan. (Figure 6) is spread in western parts of the Balkans and wider. It belongs to the Illyric floristic element (Rexhepi 1997). In Kosovo, it is spread in: Golesh, Golesh of Malisheva, Mirusha region, Drenica Mountain (Krasniqi 2003, 2006).

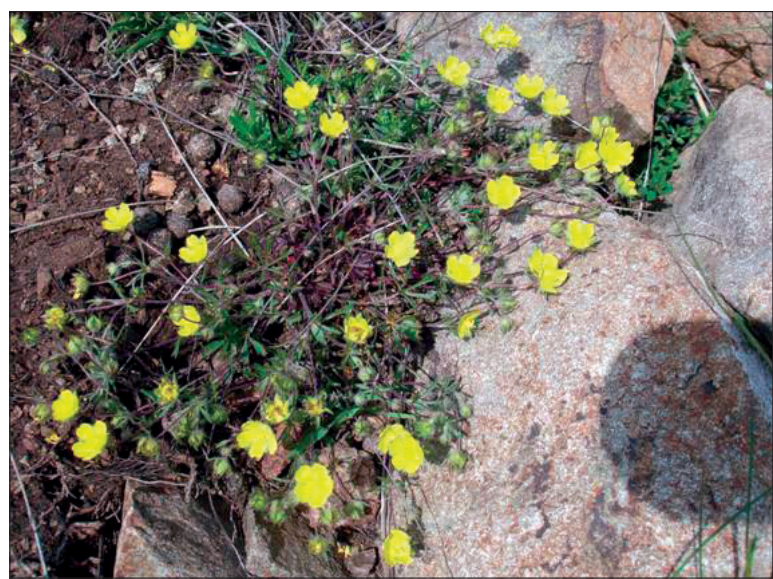

Figure 6 (Slika 6): Potentilla australis.

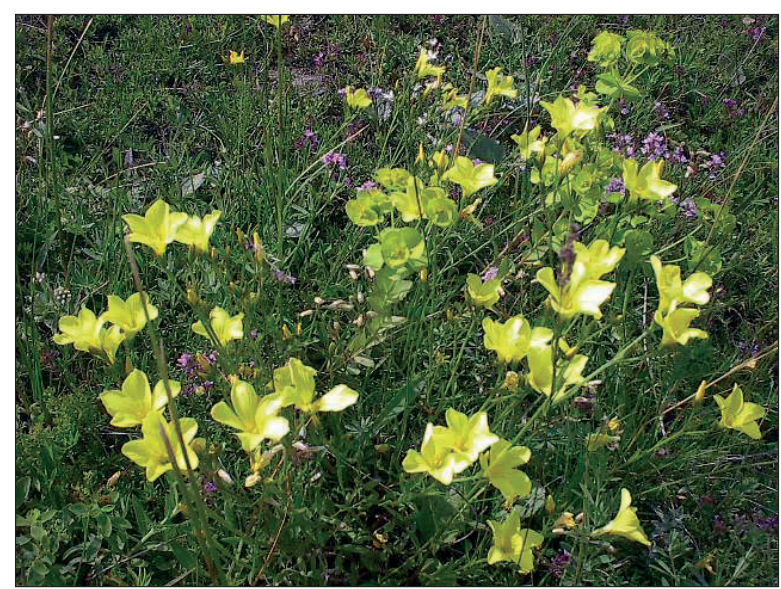

Figure 7 (Slika 7): Linum tauricum.

Linum tauricum Willd. var. serbicum (Podp.) Hayek (Figure 7) is spread in Northern parts of the Balkan Peninsula, Southern parts of Russia. It belongs to the European floristic element (European-Sub Balkans). In Kosovo, it is found in Barel, Golesh, Mirusha region, Drenica Mountain (Krasniqi 2003, 2006).

Potentilla visianii Pancic (Figure 8) is spread throughout the Balkan Peninsula. It belongs to the Balkans floristic element-Balkan Endemic (Rex-

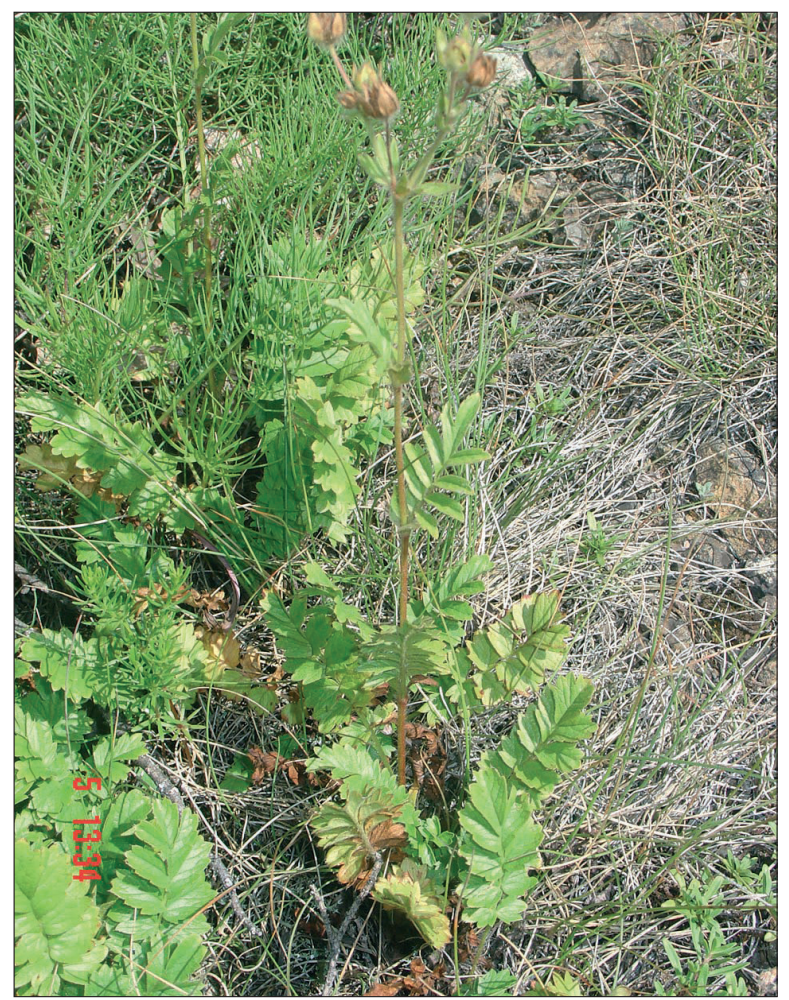

Figure 8 (Slika 8): Potentilla visianii. 
hepi 2000). In Kosovo, it is found in the Albanian Alps, Kopaonik, Golesh, Pashtrik, Mirusha region and Drenica Mountain (Krasniqi 2003, 2006).

\subsection{Community description}

Stands of the association Hyperico - Euphorbietum glabriflorae Rexhepi 1978 are found in Golesh, Koznicë, Barel, Picel and Mirusha region (Rexhepi 1994). It develops primarly on warm and dry soils. The altitude of these areas of distribution terrains is from $600-1000 \mathrm{~m}$ and even higher. There are mostly of south and south-eastern aspect, while the slope inclination is $20-45$ degrees. The soil is relatively degraded - typical rendzina on serpentine. The vegetation does not cover the entire surface and there is much bare rock on the surface. The degradation of soils and vegetation is evident. The characteristic species of the community are: $E u$ phorbia glabriflora, Thymus lykae, Potentilla visianii, Hypericum barbatum, Linum tauricum and Scorzonera austriaca, and with lower presence: Alyssum markgrafii, Plantago subulata, Stachys recta, Potentilla astrachanica, Echium rubrum, Teucrium montanum, Astragalus onobrychis, Dorycnium pentaphyllum, Stachys scardica, Minuartia verna, Aster linosyris etc.

Table 1 presents relevés made in the period 2003-2005 on Drenica Mountain. Species composition indicates warm, dry sites on serpentine bedrocks.
Association Hyperico - Euphorbietum glabriflorae Rexhepi 1978 (Figure 9) belongs to the alliance Centaureo-Bromion fibrosi Blečić et al. 1969, which is represented with a considerable number of species with constancy class V and IV: Bromus fibrosus, Plantago subulata, Alyssum markgrafi, Galium lucidum (Rexhepi 1978, 1982, 1994, 2007). Also the order Halacsyetalia sendtneri Rt. 1970 (Rexhepi 1982, 2007) is represented with a considerable number of species with constancy class V and III, such as Potentilla astracanica $[P$. hirta], Astragalus onobrychis, Halacsya sendtneri and Echium rubrum.

The class Festuco-Brometea Br. Bl. et R. Tx. 1943 (Rexhepi 1978, 1994, 2007), is represented with 10 characteristic species which have the constancy class V and IV. These are: Sanguisorba minor, Dorycnium pentaphyllum, Cerastium arvense, Aster linosyris, Stachys recta, Stachys scardica, Artemisia alba, Convolvulus cantabrica and Hippocrepis comosa. Species Eryngium campestre and Euphorbia cyparissias have constancy III, while species Campanula glomerata, Filipendula vulgaris, Galium verum, Thalictrum minus and Carex caryophyllea have constancy II.

The ecological characteristics of association $\mathrm{Hy}$ perico - Euphorbietum glabriflorae are presented by the life forms analysis (Figure 10). The graph represents the relationship given in percentages between different life forms: $\mathrm{H}(79 \%)$, Ch $(7 \%)$, and $\mathrm{G}(5 \%)$. According to the biological spectrum, we may indicate this community as hemicryptophytic.

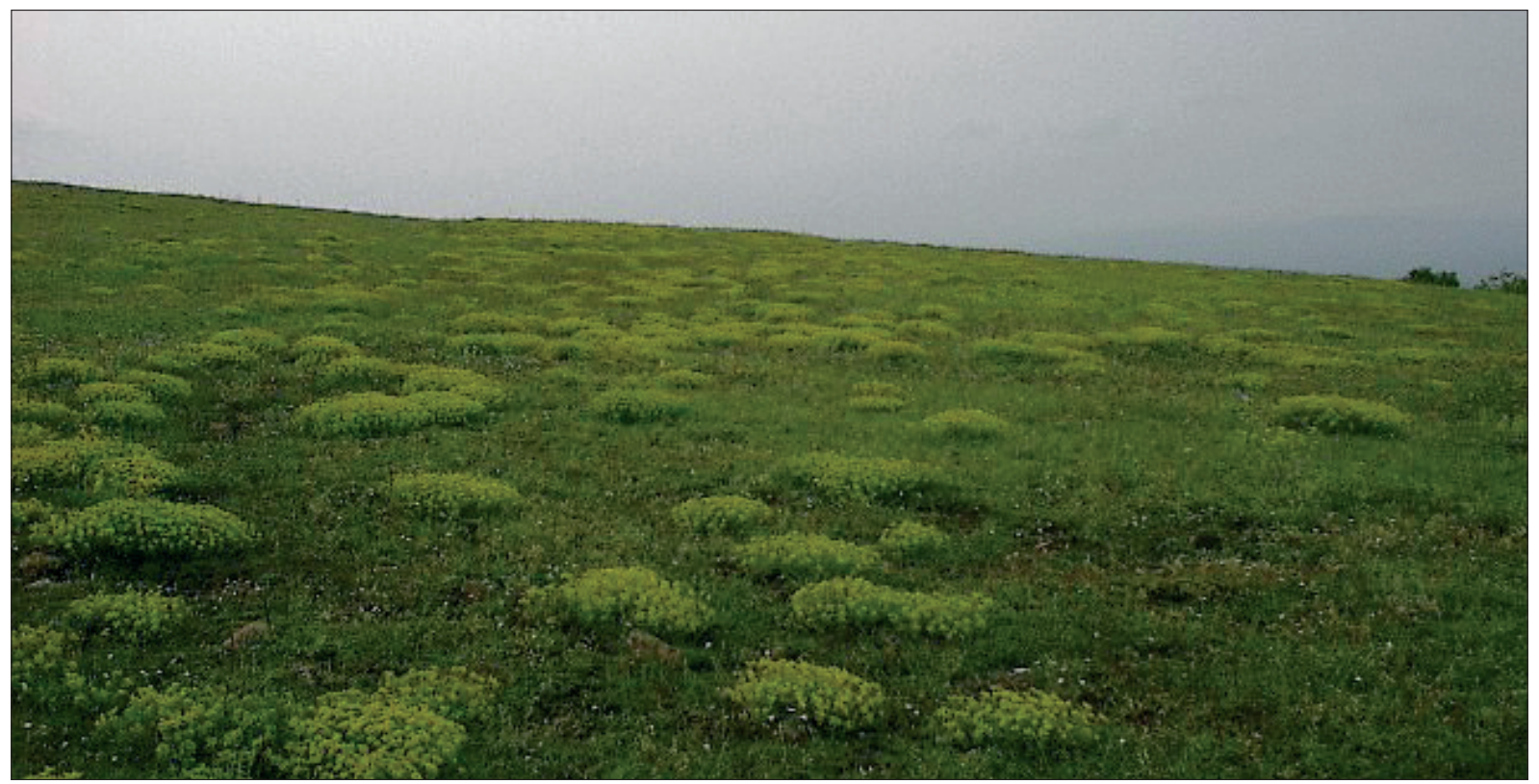

Figure 9: Association Hyperico-Euphorbietum glabriflorae (Drenica Mountain 2004).

Slika 9: Asociacija Hyperico-Euphorbietum glabriflorae (pogorje Drenica 2004). 


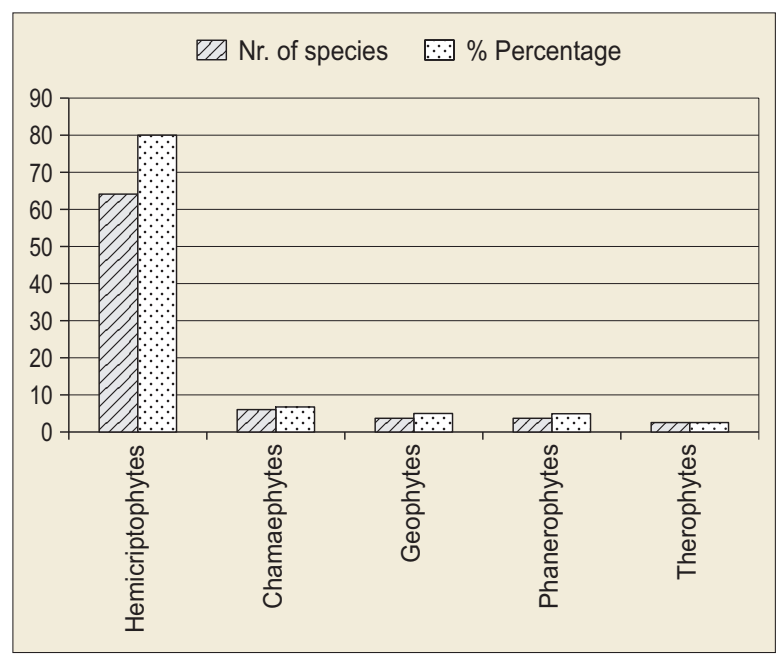

Figure 10: The biological spectrum of association HypericoEuphorbietum glabriflorae.

Slika 10: Biološki spektrum asociacije Hyperico-Euphorbietum glabriflorae.

The biogeographical affiliation of this community can be illustrated by the species areal spectrum (Figure 11). Floristic elements of the community are: European (24\%), Euro-Asiatic (21\%), Sub-Mediterranean (14\%), Pontic (13\%), Balkan (11\%), Cosmopolitan (5\%), Circumpolar (4\%), Illyric (4\%), Mediterranean (3\%) and Boreal (1\%). The southern thermophilous elements (Balkans, Mediterranean and Sub-Mediterranean) characterize the community to be of xerothermophilous character.

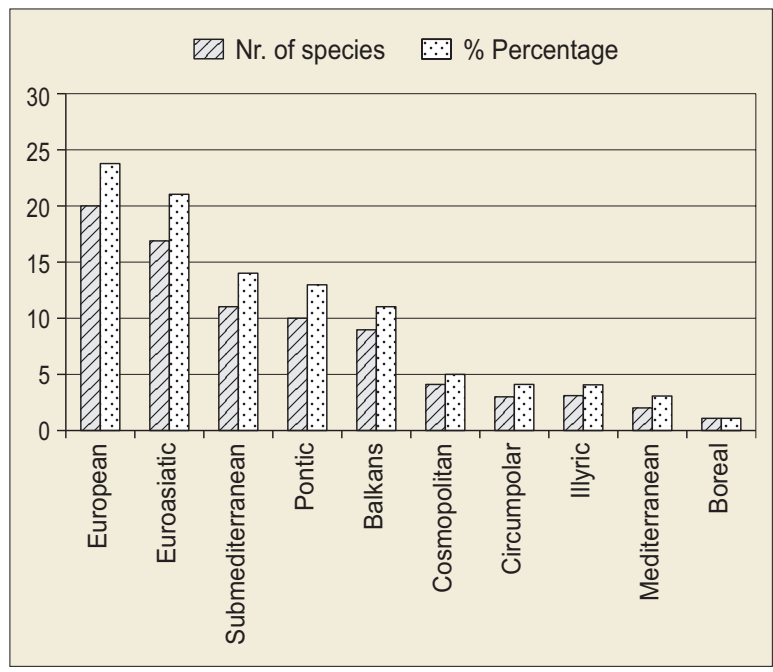

Figure 11: The areal spectrum of ass. Hyperico-Euphorbietum glabriflorae.

Slika 11: Fitogeografski spektrum asociacije Hyperico-Euphorbietum glabriflorae.
This community has no relevant economic importance, but it is important as a natural protector against soil erosion.

\section{SUMMARY}

The area of Drenica Mountain, includes terrains with different substrates and natural habitats, where the major part is covered by forests and the remaining parts are grasslands and paddocks. A considerable part of the area of this mountain consists of serpentine substrate (Pavičević et al. 1974, Krasniqi 2006).

According long-term data provided, the Drenica Mountain area has a continental climate, time-totime hostile, under the influence of wind from the Northeastern part of the region (Tahirsylaj 2004).

In the area of Drenica Mountain 10 communities have been identified. On the serpentine bedrock of Drenica Mountain two grassland communities have been identified: Hyperico-Euphorbietum glabriflorae Rexhepi 1978 and Potentillo-Fumanetum bonapartei Rexhepi 1979 (Krasniqi 2006). These communities thrive on rocky sites and are found also in other localities in Kosovo territory only on serpentine terrains (Rexhepi 1994, Krasniqi 2006).

Ass. Hyperico - Euphorbietum glabriflorae Rexhepi 1978 is spread in Golesh, Koznicë, Barel, Picel and Mirusha region. It develops mostly in dry-warm sites. The altitude of these sites is from 600-1000 $\mathrm{m}$ and even higher. There are mostly South and South -Eastern aspects, while the slope is $20-45$. The land is relatively degraded - typical rendzina on serpentine bedrock (Rexhepi 1978, 1994).

During the researching period 2003-2005 on Drenica Mountain, the state of the community was evaluated, as indicated in Table 1. According to the presence of the characteristic species, it is evident that the community is mainly linked to dry and warm sites over serpentine bedrock.

According to the measurements made with GPS, the community Hyperico-Euphorbietum glabriflorae is situated at altitude $730-895 \mathrm{~m}$ (coordinates: $\mathrm{X}=0490902$ and $\mathrm{Y}=4708414)$. The slope is 5-30 and the dominant aspect is Northeast and North. The land is relatively degraded - brownized rendzina on serpentine (Pavičević 1974, Krasniqi 2006). This is the first record of this association on Drenica Mountain.

Ass. Hyperico - Euphorbietum glabriflorae Rexhepi 1978 belongs to the class Festuco-Brometea Br. Bl. et R. Tx. 1943, order Halacsyetalia sendtneri Rt. 1970 
and alliance Centaureo-Bromion fibrosi Bleč. et al. 1969 (Rexhepi 1978, 1982, 1994, 2007).

In the table, 80 species can be found. Characteristic species of association are Euphorbia glabriflora, Potentilla australis, Linum tauricum var. serbicum, Hypericum barbatum, Potentilla visianii and Scorzonera austriaca.

According to the biological spectrum, we may conclude that in this case we are dealing with a hemicryptophyte community.

The southern and thermophilous elements (Balkans, Mediterranean and Sub-Mediterranean) give to the community of a xerothermophilous character.

This community does not have any relevant economic importance, but it is important as a natural protector of the land against erosion.

\section{APPENDIX}

Species in one relevé only:

Allium cupanii 5: +.1, Anthemis montana 10: 1.1, Armeria canescens 1: +, Asyneuma limonifolium 10: +, Bupleurum flavicans 7: 1.2, Centaurium erythraea 10: 1.1, Chamaespartium saggitale 10: 1.2, Cheilanthes maranthae 3: +, Conyza canadensis 9: +, Fritillaria messanensis 9: +, Helianthemum nummularium 2: 1.2, Lotus corniculatus 9: 1.2, Melanpyrum cristatum 9: +.1, Muscari racemosum 9: +, Potentilla argentea $6:+$, Quercus pubescens 10: + , Scilla autumnalis $6:+.2$.

\section{ACKNOWLEDGEMENTS}

We would like to thank Prof. Dr. Ferat Rexhepi for professional collaboration and Prof. Rizah Hajdari for translating the article into English.

\section{REFERENCES}

Blečić, V., Tatić, B. i Krasniqi, F. 1969: Tri endemične zajednice na serpentinskoj podlozi Srbije. Acta Botanica Croatica, XXVIII, 43-47, Zagreb.

Blečić, V., Krasniqi, F. 1971: Zajednica endemičnog šibljaka forzicije i krtušca (Polygalo-Forsythietum europaea) u jugozapadnoj Srbiji. Glas. Repub. Zav. Zaš. Prir. Muz. Titograd, 4: 35-40.

Braun Blanquet, J. 1964: Pflanzensoziologie. Grudzuge der Vegetationskunde. 3. Aufl. Springer Verlag, Wien, 865 pp.
Buzo, K. 2005: Gjeobotanika. SHBLU, Tiranë, 292 pp.

Čarni, A., Konstandinovski, M. \& Matevski V. 2000: „Saum“ (fringe) vegetation (Trifolio-Geranietea) in the Republic of Macedonia, Acta Botanica Croatica 59(1): 279-329.

Hundozi, B. 1980: Vegetacija niskih livada na Kosovu. PhD thesis, Zagreb, 175 pp.

Hundozi, B. 1987: Salvio-Scorzoneretum villosae. Buletini i punimeve shkencore, FSHMN, 132-138, Prishtinë.

Jordanov, D. (ed.) 1963-1982: Flora na NR Bulgaria I - VIII. BAN. Institut po botaniku s botanička gradina (glavni redaktor Daki Jordanov), Sofia.

Josifovič, M. (ed.) 1970-1986: Flora S.R. Srbije I-X, SANU, Beograd.

Krasniqi, E. 2003: Flora vaskulare e Rajonit të Mirushës, Punim i magjistraturës, UP, FSHMN, Prishtinë, 219 pp.

Krasniqi, E. 2006: Flora dhe vegjetacioni i Malit Drenicë, PhD thesis, UP, FSHMN, Prishtinë, 240 pp.

Krasniqi, E. \& Millaku, F. 2004: Aster albanicus Deg., përhapja në Shqipëri e Kosovë, vitaliteti ekologjik dhe vendndodhje të reja në territorin e Kosovës, Studime Biologjike 9: 120-125, Tiranë.

Krasniqi, F. 1972: ك̌umska vegetocija brdskog regiona Kosovo, Zajednica Naučnih Ustanova Kosovo, Studije, Knjiga 27, Priština, 133 pp.

Krasniqi, F. 1987: Endemics in flora of Kosovo and the problem of their protection. ANU BiH. Posebna izdanja, Odjeljenje Prirodnih i Matematičnih Nauka, Sarajevo, 14: 119-124.

Krasniqi, F. 1998: Veçoritë e florës dhe të vegjetacionit të Kosovës dhe problemi i mbrojtjes së tyre, ASHAK- Seksioni i Shkencave të Natyrës, Prishtinë. Kërkime 6: 51-66.

Kruckeberg, A. 1985: California serpentines: Flora, vegetation, geology, soil and management problems. University of California Press, 180 pp.

Mucina, L., Grabherr, G. \& Ellmauer Th. 1993: Die Pflanzengesellschaften Osterreichs, Teil I. Antropogene Vegetation (Festuco-Brometea), Gustav Fischer, Stuttgart, 421-484.

Paparisto, K. et al. 1988: Flora e Shqipërisë 1, (Akademia e Shkencave të RPSSH, Qendra e Kërkimeve Biologjike), Tiranë, 460 pp.

Paparisto, K. et al. 1992) Flora e Shqipërisë 2 (Akademia e Shkencave të RSH, Qendra e Kërkimeve Biologjike), Tiranë, 446 pp.

Qosja, Xh. et al. 1992): Flora e Shqipërisë 3 (Akademia e Shkencave të RSH, Qendra e Kërkimeve Biologjike), Tiranë, 331 pp. 
Pajazitaj, Q. 2000: Hulumtime fitocenologjike të vegjetacionit ruderal të Kosovës, Dusertacion i doktoratës, UP, FSHMN, 23-26, Prishtinë.

Pajazitaj, Q. 2004: Përcaktues i bimëve Pteridofite dhe Spermatofite, UP, Prishtinë, 397 pp.

Pavičevič, N. et al. 1974: Harta pedologjike e KSA të Kosovës (Shkalla 1: 50 000), Instituti i Ekonomisë Ujore, Beograd.

Polunin, O. 1997: Flowers of Greece and the Balkans (a field guide), Oxford Universsity Press, Oxford, New York, Tokyo, 592 pp.

Rexhepi, F. 1978: Zeljaste zajednice brdskog regiona Kosovo. PhD thesis, 113-121, Novi Sad.

Rexhepi, F. 1979: Kontribut për njohjen e florës së serpentines në Kosovë, Bioteknika, Prishtinë 1-2: 53-70.

Rexhepi, F. (1982: Vegjetacioni i Kosovës dikur dhe sot, Përparimi 2 dhe 3, Prishtinë, 2: 229259, 3: 383-422.

Rexhepi, F. 1985: Mbrojtja e florës dhe Vegjetacionit në serpentinet e Kosovës, Prishtinë, EKMN, Natyra e Kosovës 5: 61-72.
Rexhepi, F. 1994: Vegjetacioni i Kosovës (1), UP, FSHMN, Prishtinë, 161 pp.

Rexhepi, F. 1997: Mediterranean, Submediterranean and Illyric floristic elements in the Kosovo flora (Yugoslavia). Bocconea 5(2): 451-456.

Rexhepi, F.(2000: Bimët endemike të Kosovës, UP, Prishtinë, $150 \mathrm{pp}$.

Rexhepi, F. 2007: The vegetation of Kosovo (1), Mapgraphition and phythocenological investigation (Complementary edition in English), UP, FNS, Prishtinë, 137 pp.

Rexhepi, F. \& Millaku, F. 1996: Gjinia Potentilla L. në Ballkan, Buletini i FSHMN-së Nr.11, 161168, Prishtinë.

Tahirsylaj, S. 2004: Kushtet klimatike në Kosovë, Simpoziumi i vreshtave, Gjakovë.

Tutin, T. G. et al. 1964-1980: Flora Europaea 1-5, Cambridge, University Press.

Vangjeli, J. et al. 2000: Flora e Shqipërisë 4 (Akademia e Shkencave të RSH, Instituti i Kërkimeve Biologjike), Tiranë, 502 pp.

Recieved 5. 2. 2007

Revision recieved 11.5. 2007

Accepted 13. 6. 2007

Table 1: Association Hyperico-Euphorbietum glabriflorae Rexhepi 1978.

Tabela 1: Asociacija Hyperico-Euphorbietum glabriflorae Rexhepi 1978.

\begin{tabular}{|c|c|c|c|c|c|c|c|c|c|c|c|}
\hline & Nr. of relevés & 1 & 2 & 3 & 4 & 5 & 6 & 7 & 8 & 9 & 10 \\
\hline & Locality & \multicolumn{10}{|c|}{ Nekoc (Near "Zabeli i Plakiqëve") } \\
\hline & Altitude (m) & 895 & 875 & 850 & 830 & 800 & 750 & 760 & 780 & 780 & 730 \\
\hline & Aspect & NE & $\mathbf{N E}$ & NE & NE & NE & $\mathbf{N}$ & $\mathbf{N}$ & $\mathbf{N}$ & NW & NW \\
\hline \multirow[t]{3}{*}{ LF } & Slope & 15 & 10 & 5 & 5 & 5 & 15 & 20 & 20 & 25 & 30 \\
\hline & Geological substratum & & & e & $\mathbf{r}$ & & $\mathbf{n}$ & $\mathrm{t}$ & $\mathbf{n}$ & & \\
\hline & Size of relevé $\left(\mathbf{m}^{2}\right)$ & 25 & 25 & 25 & 25 & 25 & 25 & 25 & 25 & 25 & 25 \\
\hline
\end{tabular}

Char. species of ass.

$\begin{array}{llcccccccccc}\mathrm{CH} & \text { Euphorbia glabriflora } & 2.2 & 2.3 & 3.3 & 2.3 & 3.3 & 2.2 & 1.2 & 2.2 & 2.2 & + \\ \mathrm{H} & \text { Potentilla australis } & + & +.1 & + & + & + & +.2 & 1.2 & + & +.1 & + \\ \mathrm{H} & \text { Linum tauricum } & & & & & & & & & & \\ & \text { var serbicum } & + & +.2 & 1.2 & + & . & 1.2 & +.2 & + & +.2 & . \\ \mathrm{H} & \text { Hypericum barbatum } & . & 1.1 & + & + & 1.1 & 1.1 & + & . & + & . \\ \mathrm{H} & \text { Potentilla visianii } & . & + & . & 1.2 & + & 1.2 & + & 1.2 & + & . \\ \mathrm{H} & \text { Scorzonera austriaca } & + & . & . & . & . & + & + & + & . & .\end{array}$




\begin{tabular}{|c|c|c|c|c|c|c|c|c|c|c|c|}
\hline & Nr. of relevés & 1 & 2 & 3 & 4 & 5 & 6 & 7 & 8 & 9 & 10 \\
\hline \multirow{3}{*}{$\mathrm{H}$} & Char. species of All. & & & & & & & & & & \\
\hline & Bromus fibrosus & & & & & & & & & & \\
\hline & [B. erectus subsp.fibrosus] & 1.2 & + & 2.2 & 2.2 & 1.2 & 2.2 & +.2 & 1.2 & +.1 & 2.2 \\
\hline $\mathrm{H}$ & Plantago subulata & + & 1.2 & +.1 & 2.2 & +.1 & 2.2 & 2.2 & + & + & 2.2 \\
\hline $\mathrm{H}$ & Alyssum markgrafi & 1.2 & 1.2 & +.1 & 1.2 & + & 2.2 & + & 1.2 & +.1 & + \\
\hline \multirow[t]{2}{*}{$\mathrm{H}$} & Galium lucidum [G. gerardi] & +.2 & +.1 & 1.1 & +.1 & + & + & + & 1.2 & + & 1.2 \\
\hline & Char species of Ord. & & & & & & & & & & \\
\hline $\mathrm{H}$ & Potentilla astracanica & 1.2 & + & + & . & 2.2 & +.1 & 2.2 & +.1 & 1.2 & 1.2 \\
\hline \multirow[t]{2}{*}{$\mathrm{H}$} & Astragalus onobrychis & & & & & & & & & & \\
\hline & var. multijugus & + & . & + & + & 1.1 & + & 1.1 & + & . & + \\
\hline $\mathrm{H}$ & Halacsya sendtneri & . & . & . & . & . & + & 1.1 & 1.1 & + & + \\
\hline \multirow[t]{2}{*}{$\mathrm{H}$} & Echium rubrum & . & . & . & + & . & 1.1 & + & . & + & + \\
\hline & Char. species of Class & & & & & & & & & & \\
\hline $\mathrm{H}$ & Sanguisorba minor & 1.1 & 1.1 & +.1 & 1.1 & + & 1.1 & 1.1 & + & +.1 & 1.1 \\
\hline $\mathrm{H}$ & Dorycnium pentaphyllum & 1.2 & 1.2 & 1.2 & 2.2 & + & 1.2 & 2.2 & 2.2 & + & 2.2 \\
\hline $\mathrm{H}$ & Poa bulbosa & 1.1 & +.1 & + & + & +.1 & 1.2 & + & + & . & + \\
\hline \multirow[t]{2}{*}{$\mathrm{CH}$} & Cerastium arvense & & & & & & & & & & \\
\hline & subsp. ciliatus & +.1 & 1.2 & + & + & 1.1 & 1.1 & 1.2 & + & 1.1 & + \\
\hline $\mathrm{H}$ & Aster linosyris & 1.2 & + & + & 2.2 & +.1 & 1.2 & + & + & 1.2 & 1.2 \\
\hline \multirow[t]{2}{*}{$\mathrm{H}$} & Stachys recta subsp. & & & & & & & & & & \\
\hline & baldaci var. chrysophaea & 1.2 & + & + & 1.2 & + & 1.2 & + & . & + & 2.2 \\
\hline $\mathrm{H}$ & Stachys scardica & 2.1 & 1.1 & + & . & . & 1.1 & 1.1 & + & 2.2 & 2.2 \\
\hline $\mathrm{CH}$ & Artemisia alba & + & 1.2 & + & . & + & . & 1.2 & +.1 & + & . \\
\hline $\mathrm{H}$ & Convolvulus cantabrica & + & 1.1 & 1.2 & + & . & + & + & 1.1 & + & . \\
\hline $\mathrm{H}$ & Hippocrepis comosa & . & + & + & 1.2 & + & +.2 & + & . & + & . \\
\hline $\mathrm{H}$ & Eryngium campestre & . & + & . & + & . & . & + & . & . & + \\
\hline $\mathrm{H}$ & Euphorbia cyparissias & + & + & . & + & . & . & + & . & + & 1.1 \\
\hline $\mathrm{H}$ & Campanula glomerata & . & . & + & . & . & + & . & + & . & . \\
\hline $\mathrm{H}$ & Filipendula vulgaris & + & + & . & . & . & . & + & . & + & + \\
\hline $\mathrm{G}$ & Galium verum & . & . & . & . & . & . & + & + & + & + \\
\hline $\mathrm{H}$ & Thalictrum minus & . & . & . & . & . & . & . & + & 1.1 & + \\
\hline \multirow[t]{2}{*}{$\mathrm{H}$} & Carex caryophyllea & . & . & . & . & + & . & . & + & . & . \\
\hline & Companions & & & & & & & & & & \\
\hline $\mathrm{CH}$ & Sedum ochroleucum & 2.2 & 1.2 & +.2 & 2.2 & 2.2 & +.1 & 2.2 & 2.2 & 1.2 & + \\
\hline \multirow[t]{2}{*}{$\mathrm{H}$} & Euphorbia barrelieri & & & & & & & & & & \\
\hline & var. thesala & 1.2 & 2.2 & 1.1 & + & 1.2 & 2.2 & +.1 & 1.2 & 2.2 & + \\
\hline $\mathrm{H}$ & Thesium ramosum & + & + & +.1 & + & + & + & + & 1.2 & + & 1.2 \\
\hline $\mathrm{H}$ & Minuartia verna & + & + & 1.2 & + & + & + & + & + & + & + \\
\hline $\mathrm{T}$ & Euphrasia pectinata & 2.2 & 1.2 & 1.2 & + & 1.2 & + & + & 1.2 & + & . \\
\hline $\mathrm{H}$ & Eryssimum diffusum & . & +.2 & + & + & +.2 & 1.2 & +.2 & + & + & +.2 \\
\hline \multirow[t]{2}{*}{$\mathrm{H}$} & Leontodon crispus & & & & & & & & & & \\
\hline & subsp. asperrimus & 1.1 & +.1 & . & 1.1 & + & 1.1 & . & + & +.1 & 1.1 \\
\hline $\mathrm{H}$ & Minuartia hamata & +.1 & 1.1 & + & + & . & +.1 & 1.1 & . & + & 1.1 \\
\hline
\end{tabular}




\begin{tabular}{|c|c|c|c|c|c|c|c|c|c|c|c|}
\hline & Nr. of relevés & 1 & 2 & 3 & 4 & 5 & 6 & 7 & 8 & 9 & 10 \\
\hline $\mathrm{H}$ & Veronica jacquini & + & + & + & +.2 & +.2 & 1.2 & +.2 & +.1 & . & . \\
\hline $\mathrm{T}$ & Cerastium pumilum & +.1 & 1.1 & + & 1.2 & +.1 & 1.1 & + & + & . & . \\
\hline $\mathrm{H}$ & Trinia glauca & + & 1.1 & 1.1 & . & 1.1 & . & + & 1.1 & + & . \\
\hline $\mathrm{G}$ & Transteinera globosa & + & + & + & . & +.1 & . & 1.1 & + & + & + \\
\hline NP & Cytisus decumbens & + & +.1 & . & + & . & + & + & 1.2 & + & 1.2 \\
\hline $\mathrm{H}$ & Rumex acetosella & 1.1 & + & . & 1.1 & + & + & + & . & + & + \\
\hline $\mathrm{H}$ & Alyssum murale & . & + & + & + & . & + & + & +.1 & + & +.1 \\
\hline \multirow[t]{2}{*}{$\mathrm{H}$} & Anthyllis vulneraria & & & & & & & & & & \\
\hline & subsp. polyphylla & +.1 & 1.2 & 1.1 & . & + & 1.2 & + & + & . & . \\
\hline $\mathrm{H}$ & Paronychia kapela & . & 1.2 & + & + & . & +.1 & +.1 & 1.2 & + & . \\
\hline $\mathrm{H}$ & Stipa pulcherrima & . & + & + & . & + & . & 1.2 & +.2 & 1.2 & 1.2 \\
\hline $\mathrm{CH}$ & Sedum album & + & . & + & . & +.1 & +.2 & . & + & +.2 & +.1 \\
\hline $\mathrm{H}$ & Centaurea splendens & + & 2.1 & . & + & . & 2.1 & . & 2.1 & + & + \\
\hline $\mathrm{H}$ & Hypericum perforatum & 1.1 & +.1 & + & . & + & 1.1 & + & . & . & + \\
\hline \multirow[t]{2}{*}{$\mathrm{H}$} & Vincetoxicum hirundinaria & & & & & & & & & & \\
\hline & (Cynanchum athoum) & + & . & . & + & +.2 & + & . & + & + & +.1 \\
\hline $\mathrm{H}$ & Scabiosa columbaria & . & + & + & + & . & + & . & + & + & + \\
\hline $\mathrm{H}$ & Hieracium praealtum & + & + & +.1 & + & . & + & . & + & + & . \\
\hline $\mathrm{H}$ & Verbascum phoeniceum & + & + & + & + & . & + & . & + & + & . \\
\hline $\mathrm{H}$ & Alyssum montanum & + & + & + & + & . & + & . & + & + & . \\
\hline $\mathrm{CH}$ & Teucrium montanum & +.2 & +.1 & +.2 & . & . & +.2 & . & . & +2 & +.2 \\
\hline G & Orchis morio & . & +.1 & . & 1.1 & + & . & . & + & +.1 & 1.2 \\
\hline $\mathrm{H}$ & Inula hirta & . & + & 1.1 & +.1 & . & + & + & + & . & . \\
\hline $\mathrm{H}$ & Silene vulgaris & + & . & . & . & + & . & + & +.1 & + & + \\
\hline $\mathrm{H}$ & Agropyron cristatum & + & + & . & + & +.1 & . & . & . & + & +.1 \\
\hline $\mathrm{H}$ & Podospermum laciniata & . & + & + & + & . & + & . & +.1 & + & . \\
\hline $\mathrm{G}$ & Orobanche gracilis & + & + & + & . & + & . & + & . & + & . \\
\hline $\mathrm{H}$ & Dischanthium ischaemum & + & + & . & + & . & + & . & + & . & + \\
\hline $\mathrm{H}$ & Briza media & + & + & . & + & . & + & . & + & + & . \\
\hline $\mathrm{H}$ & Phleum montanum & + & + & . & . & . & + & + & . & + & + \\
\hline $\mathrm{H}$ & Achillea coarctata & . & . & 1.2 & +.2 & +.2 & + & + & . & . & . \\
\hline $\mathrm{H}$ & Plantago argentea & . & + & . & + & + & + & . & + & . & . \\
\hline $\mathrm{H}$ & Linum perenne & . & . & + & + & + & . & . & + & . & + \\
\hline $\mathrm{H}$ & Onobrychis alba & . & + & . & + & . & + & + & . & . & + \\
\hline G & Iris reichenbachi & . & + & . & + & . & + & + & . & + & . \\
\hline $\mathrm{H}$ & Trifolium alpestre & + & . & + & + & . & . & + & . & . & . \\
\hline $\mathrm{H}$ & Plantago lanceolata & . & . & + & . & + & . & . & + & + & . \\
\hline $\mathrm{H}$ & Veronica spicata & . & . & . & . & . & . & +.2 & 1.2 & +.2 & . \\
\hline $\mathrm{H}$ & Hypericum rumelicum & . & . & . & . & + & . & . & 1.1 & +.1 & + \\
\hline $\mathrm{H}$ & Primula veris & . & . & . & . & . & . & + & . & + & + \\
\hline $\mathrm{H}$ & Dianthus sylvestris & . & . & . & . & . & . & . & + & + & + \\
\hline $\mathrm{P}$ & Fraxinus ornus & . & + & . & . & . & . & . & + & + & . \\
\hline $\mathrm{P}$ & Juniperus oxycedrus & . & . & . & . & . & . & . & + & + & . \\
\hline
\end{tabular}

